\title{
TGFB1 wt Allele
}

National Cancer Institute

\section{Source}

National Cancer Institute. TGFB1 wt Allele. NCI Thesaurus. Code C52015.

Human TGFB1 wild-type allele is located within 19p13. 2 and is approximately $24 \mathrm{~kb}$ in length. This allele, which encodes transforming growth factor beta-1 protein, is involved in proliferation, differentiation, and other several other cellular functions. 